\title{
Refugee Determination Complexity
}

\author{
David Matas
}

\begin{abstract}
Refugee determination systems are complex and unfair. This combination is surprising. Why has government after government in Canada and around the world generated refugee determination systems that are both complex and unfair? The answer is that governments intrude into systems that would otherwise be both simple and fair, in order to assert control. They assert control in order to achieve other, non-refugee protection objectives. These nonrefugee protection objectives are inappropriate for the design of a refugee determination system. A refugee determination system should be devised with four objectives in mind: fairness, internal consistency, simplicity, and compliance with international standards. The article examines Bill C-31 and makes recommendations for its improvement with these objectives in mind.
\end{abstract}

\section{Résumé}

Les systèmes pour la détermination du statut de réfugié sont complexes et injustes. Cette combinaison est surprenante. Comment se fait-il que gouvernement après gouvernement au Canada et partout dans le monde aient engendré des systèmes de détermination qui soient complexes et injustes? La réponse est que les gouvernements s'ingèrent dans des systèmes qui seraient autrement simples et équitables dans le but d'affirmer leur contrôle. Ils affirment leur contrôle afin d'atteindre d'autres fins qui n'ont rien à voir avec la protection des réfugiés. Ces fins non-liés à la protection des réfugiés sont impropres à la création d'un système de détermination du statut de réfugié. Un système de détermination du statut de réfugié devrait être conçu en tenant en ligne de compte quatre objectifs : équité, cohérence interne, simplicité et conformité à des normes internationales. L'article examine le projet de loi $\mathrm{C}-31$ et formule des recommandations pour son amélioration en tenant en ligne de compte ces objectifs.
$\mathrm{R}$ efugee determination systems around the world share two common features: complexity and unfairness. These features have bedevilled each form that the Canadian refugee determination procedure has taken through the years.

The old Canadian refugee determination procedure, declared unconstitutional by the Supreme Court of Canada because of its unfairness, was as complex a system as could be imagined. It was a Rube Goldberg device in which the roundabout took precedence over the direct.

Under that old procedure, a person had to violate the Immigration Act to make a refugee claim. By statute, a person could make a claim only if the person was before an adjudication tribunal convened to decide whether a violation of the Immigration Act had taken place.

In order not to create artificial incentives to violate the act, the department, by policy, instituted an in-status refugee determination system. However, the in-status system could not supplant the out-of-status statutory system, only complement it. So once the in-status procedure was in place, a person could make two refugee claims: one in-status, and a second out-of-status.

The immigration inquiry that triggered the out-ofstatus claim did not conclude with the issuance of a conditional order, as now. Rather, the inquiry just adjourned after the claim and a decision that there was a violation of the Immigration Act. The inquiry had to be reconvened after the refugee determination for a decision whether there would be a removal order or departure notice.

Both in-status and out-of-status refugee claims were made initially by talking into a tape recorder. The claimant would be convened to an interview conducted by a senior immigration officer who would tape the interview and have a transcript prepared. The transcript would be sent to the claimant for comment and then forwarded to Ottawa to a committee for its advice: the Refugee Status Advisory Committee. The committee, after reading the transcript, would advise the minister of Immigration, who would decide the claim. 
If the decision of the minister was negative, and it almost always was, the claimant then could apply for redetermination to the old Immigration Appeal Board. The application was on paper only. This paper application was not for a reversal of the decision but for an oral hearing only. The application was akin to a leave application, but the test for success was a good deal higher than for a leave application. The Immigration Appeal Board could grant an oral hearing only if there were reasonable grounds to believe, on the basis of the paper application, that the claimant, at the oral hearing, could succeed in the claim.

If the Immigration Appeal Board rejected the paper application, as was most often the case, or held an oral hearing and then rejected the case, the person then went back to the immigration adjudicator for a decision on whether a removal order or departure notice would issue. Of course, beyond all that there was recourse to the Federal Court.

Most people went through this system without ever appearing in front of anyone who decided their claim - a feature that attracted the attention of the Supreme Court of Canada. In addition, if one totals every step a person took who was rejected at every turn, there were twelve in all, even when there was no attempt to seek a remedy from the Federal Court. They were:

1. an in-status interview

2. a submission on the transcript of that interview

3. the advice of the Refugee Status Advisory Committee on the transcript

4. the decision of the minister on that advice

5. an immigration inquiry at which an out-of-status claim was made

6. an out-of-status interview

7. a submission on the transcript of that out-of-status interview

8. the advice of the Refugee Status Advisory Committee on the second transcript

9. the decision of the minister on that advice

10. an application for redetermination to the Immigration Appeal Board

11. a hearing of the claim by the Immigration Appeal Board, on the assumption that the application for redetermination was granted

12. the resumption of the immigration inquiry before an adjudicator to determine whether there should be a departure notice or deportation order

This system, bizarre as it sounds, is similar to refugee determination systems found elsewhere. Indeed, this earlier Canadian model was inspired by foreign refugee determination systems. There are even some people in Canada today nostalgic for the old system and regretful of the Supreme Court of Canada intrusion into it.

The old system, in addition to all its other faults, suffered from an absence of integration of the overseas and inland refugee determination systems. Overseas refugee determinations, performed at Canadian visa posts abroad, were made by different people using different procedures, standards, and criteria.

The inland system was so long, drawn out, and unfair that virtually everyone was being rejected, but virtually no one was being removed. The system was completely dysfunctional and had to be revamped, even without the decision of the Supreme Court of Canada ruling it unfair.

The system in the present act and regulations is an improvement, but still needlessly complex and needlessly unfair. The present act creates a bifurcated road. The number of steps depends on which of the two roads the claimant is required to take.

Under the present act, first there is a port-of-entry interview, where claimants are interviewed on arrival about the substance of their claims without access to counsel, a procedure the Supreme Court of Canada has decided is constitutionally valid. Second there is eligibility determination, conducted by a senior immigration officer.

A determination of eligibility puts claimants on one of the two roads. If the person is eligible, there is the refugee hearing conducted by the Refugee Division of the Immigration and Refugee Board. If the claim is rejected, the person can apply for membership in the post-claims refugee determination in Canada class. The decision on membership in the post-claims refugee determination in Canada class is made by a specialized corps of officers in the Department of Immigration: the post-claims determinations officers (PCDOS).

A person can make a claim either in-status or at an immigration inquiry. If the claim is made at the inquiry, then the adjudicator issues a conditional removal order. If the claim fails, the order becomes effective without the need to reconvene the inquiry.

Those found not eligible have risk determined differently from those found eligible. One ground of ineligibility is that the person has committed an offence with a maximum punishment of ten years or more and has been determined by the minister to be a public danger. A person found ineligible to make a refugee claim is also ineligible to apply for membership in the post-determination refugee claimants in Canada class. It is this public danger determination procedure that becomes, instead, the risk determination procedure. 
The public danger procedure starts with a determination in the local immigration office to seek the advice of the minister that the person is a public danger. The person concerned is notified of this determination with an opportunity to make written submissions that would be forwarded to the minister. The written submissions are sent to headquarters where they are analyzed, and advisory opinion is given. The minister or her delegate decides.

As can be seen, in this process there is never a standalone risk assessment. Rather, risk assessment is folded into the public danger determination. The ultimate decision is only that the person is or is not a public danger. Furthermore, the decision on public danger does not involve the department's risk-analysis specialists_- the post-claims determination officers.

In order to engage their involvement, the person concerned has to make a second application, this time for permanent residence on humanitarian and compassionate grounds. It is the policy of the department, when an application is made for humanitarian landing and the application has a risk component, to refer the risk component of the application to the post-claims determination officers for their advice.

The Immigration Act, in general, prevents removal of a rejected refugee claimant pending consideration of his or her application to the Federal Court. There are statutory stays of execution of removal orders. However, persons found ineligible to make a refugee claim on the basis that they are public dangers are not granted statutory stays. They must apply for judicial stays. Furthermore, an application for humanitarian landing, in itself, does not prevent execution of a removal order.

In consequence, the application for a judicial stay of execution of a removal order becomes part of the process of risk determination. Recourse to the Federal Court becomes a necessary part of the process rather than a step to be taken after the process is completed. Unless a person can stay in Canada pending his or her humanitarian application, the person never gets recourse to a decision reached on the advice of the post-claims determination officers. The department does not attempt to remove some people pending their humanitarian applications. However, as the docket of the Federal Court shows, for many, it does.

Again, with this system, there is no integration with the overseas system and the inland system. Indeed, though the inland system has changed substantially, the overseas system has remained much the same. There has been a broadening of the risk standards. However, other criteria remain in place, and the procedure is unchanged.
This lack of integration creates its own perversity. It is a policy of the Immigration Act to have applications for immigration processed at visa posts abroad, rather than inland. Yet, the refugee determination system overseas is much more problematic than the system inland.

The system is a good deal less fair. For instance, there is no right to counsel at refugee interviews, and most visa posts, as a matter of policy, prevent counsel from attending, even if they are available at the time of the scheduled interview.

The persons who decide are neither specialized nor expert in refugee matters and have only cursory training in the field. They are not independent from government and its immigration and foreign affairs objectives, but rather part of government and part of that very portion of government that pursues immigration and foreign policy objectives.

The visa posts impose criteria that are not part of the inland determination. Examples are medical admissibility, likelihood of successful establishment, and no durable solution elsewhere.

It is a good deal harder to be recognized as a refugee overseas than inland, and for all the wrong reasons. The system gives an artificial incentive for claimants to come to Canada to make their claims, working at cross-purposes with the overall objective of the system to have applications processed at visa posts abroad.

The present system is fairer than the old one, for at least some people. For those found to be public dangers, the present system is as unfair as the old system, and then some. For those who are found to be eligible, there is a fair hearing before an independent expert tribunal. The system is not completely fair, because of the denial of access to counsel at the initial port of entry interview, the absence of an appeal, and the impossibility of reopening to consider change of circumstances, new evidence, or old evidence not previously available.

As well, the present system is still needlessly complex. It is not as complex as the old system. However, there are still many unnecessary steps, consuming time and money for no apparent purpose.

Superficially, this combination of complexity and unfairness is surprising. It is easy to fathom, if not to commend, a system that is both fair and complex or simple and unfair. In a system that is both fair and complex, the complexity can be justified by the fairness. In a system that is both simple and unfair, there would be at least some who would attempt to justify the unfairness by the simplicity. However, why has government after government in Canada 
and around the world generated refugee determination systems that are both complex and unfair?

The reason is the intrusion into these systems of yet another objective besides simplicity and fairness: the objective of control. Governments intrude into a system that would otherwise be both simple and fair, in order to assert control over the system.

The reason for that attempt to assert control is that refugee protection systems impinge upon other government policy objectives. Refugee claimants who get protection get to stay. Those who get to stay become part of the local community. The governments want a say in who gets to stay. So they intrude into refugee determination systems in order to attempt to realize their immigration objectives.

As well, a decision that a person is a refugee is a decision that the country of danger fled is a country of persecution. For some governments, that is a judgment that they would rather not have made of their allies. Refugee determination can conflict with foreign policy objectives.

For Canada, immigration and foreign policy concerns are less than for many others. Canada attempts to promote human rights abroad in a neutral fashion. Canada is a country of immigration. Recognizing refugees can support Canada's foreign affairs and immigration policies rather than contradict them.

As well, it is not that easy to get to Canada. The only country with which Canada has a land border is the United States, which does not produce refugees. Every refugee claimant coming to Canada has to either traverse the United States or arrive by air or sea.

The number of those arriving by air or sea can be controlled by visa requirements and carrier sanctions. Canada has visa requirements on every country producing significant numbers of refugee claimants; denies visas systematically to everyone who wants to come to Canada to make a refugee claim; and penalizes commercial carriers who bring to Canada persons who need visas but do not have them. This interconnected web of visa requirements, visa denials, and carrier sanctions reduces the number of arrivals to Canada to the point where, even if Canada were to accept as a refugee every refugee claimant that got to Canada, the numbers would be manageable.

The Canadian policy concerns about immigration numbers from refugee recognition inland, as a result, are inappropriate. To a large extent, the present design of the inland refugee determination system manages to avoid an unwarranted intrusion of immigration considerations into refugee determinations because, at least for those eligible to make a claim, risk determination is done by an independent tribunal - the Immigration and Refugee Boardand not the Immigration Department.

Immigration concerns intrude more readily into refugee determination overseas because those refugees determinations are done by visa officers who otherwise decide on immigration matters. Many refugees abroad, as well as in Canada, would not qualify for permanent residence if they were not refugees. That should not matter and, in general, does not matter to members of the Refugee Division of the Immigration and Refugee Board. It is, however, something that tugs at the minds of visa officers. It becomes impossible for many, if not most, visa officers to separate their refugee protection tasks from their immigration tasks.

It is this failure to separate refugee determination from immigration that explains the superficial perversity of a system that works with much less success abroad than in Canada. Officials seem not to care that the system creates an incentive to get to Canada, because they know that the web of visa requirements, visa denials, and carrier sanctions will prevent the arrival of most of those who want to come.

The other policy concern that unduly intrudes into Canadian refugee protection is a concern about criminality. International law says that no one, no matter what the crime, should be returned to torture, disappearance, or arbitrary execution. Refugees who are also criminals can be returned to danger, but only if the danger they face on return is less than the danger they pose to the community where they seek protection. For Canadian policy makers, this protection of criminals goes too far. Canadian law intrudes into refugee protection to prevent it from happening.

We should approach the refugee determination system with these objectives in mind: The system should be fair. It should be simple. It should comply with international law standards. It should be consistent and integrated, not working at cross-purposes.

The system proposed in the government's Bill c-31, introduced in the last Parliament, though in some respects an improvement over the present law, is still not quite right. It is still needlessly complex and unnecessarily unfair. It suffers from a lack of integration. And it does not fully comply with standards of international law.

The proposed system, like the old one, creates a bifurcated road. Some claimants will be found eligible and go through one form of risk determination at the level of the Protection Division of the Immigration and Refugee Board. 
Other claimants will be found ineligible and go through another form of risk determination-an administrative pre-removal risk assessment.

Perhaps it is more accurate to say that the old system, like the new one, creates a trifurcated road. A third group of claimants go down a third, dead-end, road. At the end of this third road there is removal without any form of risk assessment whatsoever.

The criterion for public danger disappears. Bill c-31, though removing the public danger label, makes matters worse. Rather than a there being a double hurdle for ineligibility, as there is now, of a crime with a high maximum sentence plus a public danger determination, there will be only a single hurdle of a conviction of a crime with a high maximum sentence.

Under the bill, once a person is declared ineligible, the person goes into a different risk determination stream. Risk determination is made not by the Protection Division of the Immigration and Refugee Board, but through preremoval risk assessment. The bill gives the power to decide on pre-removal risk assessment to the minister of Citizenship and Immigration, but also allows her to delegate that power to decide. Under the bill, the definition of risk that both the Protection Division of the Immigration and Refugee Board and pre-removal risk assessment officials would consider is the same.

So, the bill contemplates two streams of claimants, going into two different determination systems where the risk definition applied would be the same, and where the procedure for application of the definition could be the same. Furthermore, eligible but rejected refugee claimants would be able to go into pre-removal risk assessment, in effect getting two refugee determinations.

As problematic as fragmentation of the refugee determination system is, even more problematic is the situation of those who are unable to squeeze into any one of the fragments. Those rejected as refugees or found ineligible to make a claim, as well as those who have abandoned or withdrawn their claims, cannot apply for refugee determination if they have left Canada and then returned. They cannot apply for pre-removal risk assessment either, where the return is within a year of the departure.

Another gap in protection, both under the present law and the bill, is protection from danger for a person recognized as a convention refugee by another country who can be returned to that country. The gap should be addressed. To do that, we need an amendment to the definition of " $\mathrm{a}$ person in need of protection" in the bill.

In addition to the unnecessary steps of ineligibility and pre-removal risk assessment, with roughly parallel steps in the present system, the bill adds a new step not found in the present system. It is the need to apply for a judicial stay of execution of a removal order to keep the person in Canada pending an application for leave and judicial review of a negative refugee determination by the Refugee Appeal Division of the Immigration and Refugee Board.

The bill, like all its predecessors, does little to address the connection between the refugee determination overseas and refugee determination in Canada. Indeed, although the bill provides a common definition for refugee protection, it puts claimants outside Canada through the procedures and provisions of part 1 of the act dealing with immigrants and not through part 2 of the act dealing with refugees.

What follows are specific recommendations about Bill C-31 in line with this general approach, dividing them among the four objectives stated. Some of these recommendations, of course, serve more than one objective.

\section{Simplification}

1. Everyone in Canada should be eligible to make a refugee claim. There should be no ineligibility step before refugee determination. The eligibility step is unnecessary for most claimants, since most claimants are eligible. The step just takes up time and money.

People ineligible because of war crimes, crimes against humanity, or serious non-political crimes committed before entry can be denied refugee protection under the convention exclusion clauses. A person ineligible to make a refugee claim if the person has been found to be a convention refugee by another country, and can be returned to that country, can be dealt with under the Refugee Convention clause, excluding from the refugee definition those having the rights and obligations attached to the possession of nationality of another country.

People who have committed serious crimes in Canada and are a danger to Canada, and people who are security risks, can be removed from Canada even if refugees. Refugee determination in this case assists in the decision whether to remove by providing an assessment of the gravity of risk faced on return.

People who have passed through a designated safe third country are ineligible under the present act, but no country has ever been designated, for good reason. None ever should be. Safety should always be determined case by case, for every country of return.

People already recognized or refused as refugees can be dealt with through the doctrine of res judicata. The doctrine of res judicata does not prevent the examination of new evidence. It does prevent the relitigation of old issues 
between the same parties on the same evidence. No tribunal will again hear a case it has already decided simply because a party requests the rehearing.

People who have withdrawn or abandoned claims can be dealt with through the doctrine of abuse of process. Again the doctrine of abuse of process does not prevent reconsideration of a case withdrawn or abandoned, if there is good reason for reinstituting the case. It does prevent coming to court constantly on a whim.

2. There should be no administrative pre-removal risk assessment procedure but instead a re-opening jurisdiction in the Protection Division of the Immigration and Refugee Board paralleling the existing re-opening jurisdiction of the Appeal Division of the Immigration and Refugee Board. That is to say, there should be a power to reopen, on application, where there is a change of circumstances in the country of claim, new evidence in support of the claim, or old evidence not previously available.

3. It should not be necessary to apply for a discretionary stay to the Federal Court. There should be, as now, a statutory stay pending applications for leave.

\section{Fairness}

4. There should be a right to counsel at port of entry refugee interviews.

5. If there is an administrative pre-removal risk assessment procedure, there should be an oral hearing under this procedure, at the very least, for those who had no oral hearing from the Protection Division of the Immigration and Refugee Board.

6. Even if there is an administrative pre-removal risk assessment procedure that considers change of country conditions, there should be a reopening jurisdiction in the board to consider new evidence or old evidence not previously available. It is difficult for an instance that has not made the original determination to decide whether or not new evidence or old evidence not previously available would change that determination.

7. In order to ensure a refugee determination procedure that brings to its task no bias, or reasonable apprehension of bias, Parliament should legislate a transparent, professional, and accountable selection procedure for members of the Immigration and Refugee Board.

8. It should be possible to appeal from abandonment decisions. Abandonment can be hotly contested. A claimant may not show up for a prior hearing because he or she never received notice of the hearing. The board must then decide whether what the claimant did to maintain contact with the board in order to receive notice was reasonable in the circumstances. An appeal from a contested abandonment decision where risk is at issue, is as appropriate as an appeal from the risk decision itself.

9. A person should be allowed to make a refugee claim, whether or not the person is under a removal order. Often whether such a claim is made or not depends on the person's awareness of his or rights at the time of removal proceedings. A removal order can be made on arrival, at the port of entry, before the claimant has had access to counsel. The denial of substantive rights should not depend on procedural vagaries.

\section{Compliance with International Law}

10. If there is both an eligibility stage and an administrative pre-removal risk assessment stage, everyone who is ineligible for consideration by the Protection Division of the Immigration and Refugee Board should be eligible for consideration under the pre-removal risk assessment procedure. No one at risk should be removed from Canada without assessment of that risk.

11. The bill should grant both the power to prevent removal to generalized risk and to risk that may not be so general as to put everyone at risk, but general enough to be faced "generally by other individuals in or from that country," that is to say those similarly situate to the claimant. The risk may not be faced by the foreign national in every part of the country, but it may be faced in the part of the country to which the department would remove the applicant, the place where the international airport is to be found.

As well, there should be provision to allow for suspension of removals based on the application of individuals. It should be possible for a decision on suspension to be responsive to the testimony that individual refugee claimants have to give.

12. There needs to be mechanism for dealing with danger in a country that has granted the person refugee status and to which the person could be returned, but for that danger. One way of dealing with that danger is through the definition of a person in need of protection. The definition of person in need of protection could read, "A person in need of protection is a foreign national in Canada whose removal to any country to which the person can be removed would subject her personally ..."

13. For generalized risk, in addition to gaps in protection coverage, there are failings in due process, now and in the proposed bill. The present power to prevent removal to generalized risk has been exercised in an opaque and arbitrary fashion, behind closed doors. Individuals are faced 
with a decision that they do not request and to which they do not contribute.

There needs to be an open and fair procedure to invoke the power to prevent removal to generalized risk. This procedure should be part of the refugee determination process. Every claimant should be able to request a determination that the risk the person faces would be faced by the person in every part of that country and is faced generally by other individuals in or from that country.

14. The bill should prohibit the removal of anyone to torture, arbitrary execution, or disappearance. As mentioned earlier, international law prohibits such removal.

\section{Integration with the System Overseas}

15. Refugee determinations overseas should be done by the Protection Division of the Immigration and Refugee Board, using the same procedures as in Canada.

16. At the very least, the bill should recognize there is a right to counsel at refugee interviews at visa posts abroad.

17. As long as the refugee determination procedure overseas remains the same as it is now, the bill should provide for eligibility to make an inland claim where the person is rejected overseas.

\section{Conclusion}

There was an elaborate policy process leading up to Bill c31. The bill was preceded by the report of an independent Legislative Review Advisory Group and a ministerial white paper. Both involved extensive cross-Canada consultations.

Yet, the new bill suffered from the same vices as the present legislation: complexity, unfairness, internal inconsistency, and deviance from international standards. It seems that even the most extensive review and consultations could not shake the policy makers from a few strongly held beliefs, though it was those very beliefs that had led to the current impasse.

What is needed now is not just a new bill, but new thinking. Immigration and refugee reform has for so long been mired in the past, it is hard to be optimistic that a new day will dawn.

David Matas is a lawyer in private practice in Winnipeg and a contributor to the Canadian Bar Association brief on Bill C-31. 